\title{
Epidemic spread of Puccinia hemerocallidis in Brazil
}

\author{
E. M. Inokuti • D. J. Soares • R. W. Barreto
}

Received: 7 October 2011 / Accepted: 4 November 2011 /Published online: 10 January 2012

(C) Australasian Plant Pathology Society Inc. 2012

\begin{abstract}
Since the first report of daylily rust (Puccinia hemerocallidis) in Brazil in the state of São Paulo in 2001, it spread during that decade and is now found in a very broad area encompassing central, northeastern, southern and southeastern Brazil. It is now regarded as one of the major disease problem for this popular ornamental. Events in Brazil were equivalent to those of the epidemic spread of $P$. hemerocallidis in the US which occurred around the same period.
\end{abstract}

\section{Keywords Ornamental · Pucciniaceae $\cdot$ Quarantine}

Daylilies (Hemerocallis flava, H. fulva and hybrids Hemerocallidaceae) are perennial rhizomatous plants from Eurasia that are valued herbaceous ornamentals worldwide. One of the most serious disease of daylilies is rust caused by Puccinia hemerocallidis. This disease was originally restricted to the host's native range but spread to North America in 2000, Oceania in 2002, Central America and the Caribbean in 2006 (Smith 2009).

E. M. Inokuti $\cdot$ D. J. Soares $\cdot$ R. W. Barreto $(\square)$

Departamento de Fitopatologia, Universidade Federal de Viçosa,

Viçosa, MG 36570-000, Brazil

e-mail: rbarreto@ufv.br

Present Address:

D. J. Soares

Embrapa Algodão, Cx.P: 174,

Rua Osvaldo Cruz, 1143, Centenário,

Campina Grande, PB 58428-095, Brazil
The first record of $P$. hemerocallidis in Brazil was by Carvalho et al. (2001) from the state of São Paulo based on the observation of urediniospores. Later its telial stage was observed in the state of Bahia, confirming its occurrence in Brazil (Menezes et al. 2008). Independently, additional collections of the same rust were made in Viçosa - Jul 2007 (state of Minas Gerais), Nova Friburgo- Mar 2010 (state of Rio de Janeiro), Brasília- Aug 2007 (Distrito Federal) and Balneário Camboriú - Oct 2011 (state of Santa Catarina). Representative specimens were deposited in the local herbarium (Herbarium VIC) under the following respective accession numbers: 31312, 31314, 31315, 31313 and 31765.

Morphology was as follows: lesions initially punctiform becoming elongated $0.5-5.5 \times 0.5-1.5 \mathrm{~mm}$, surrounded by necrotic zones; uredinia subepidermal $100-310 \mu \mathrm{m}$ wide; urediniospores, globose to ellipsoid, 17-29 $\times 15.5-23 \mu \mathrm{m}$, walls $1-3 \mu \mathrm{m}$ thick, pale yellow, echinulate; telia emerging from old uredinia, teliospores bicellular, ellipsoidal to clavate, pedicelate, $33-48 \times 10.5-20 \mu \mathrm{m}$, apical wall 2 $5.5 \mu \mathrm{m}$, lateral wall $0.5-1.5 \mu \mathrm{m}$, brown, smooth, pedicels 2-7.5 $\mu \mathrm{m}$ wide (Fig. 1a-e)

Quarantine measures in the USA failed to control the introduction and spread of Puccinia hemerocallidis (Wise et al. 2004). It was first detected in the US in 2000 but in 2002 USDA PPQ lifted the federal quarantine on this pathogen, because it was already present in over 24 states. In Brazil it was never listed as a quarantine pest. It also spread fast in Brazil since being first recorded in 2001 and is now present in the Northeast, Center, Southeast and 

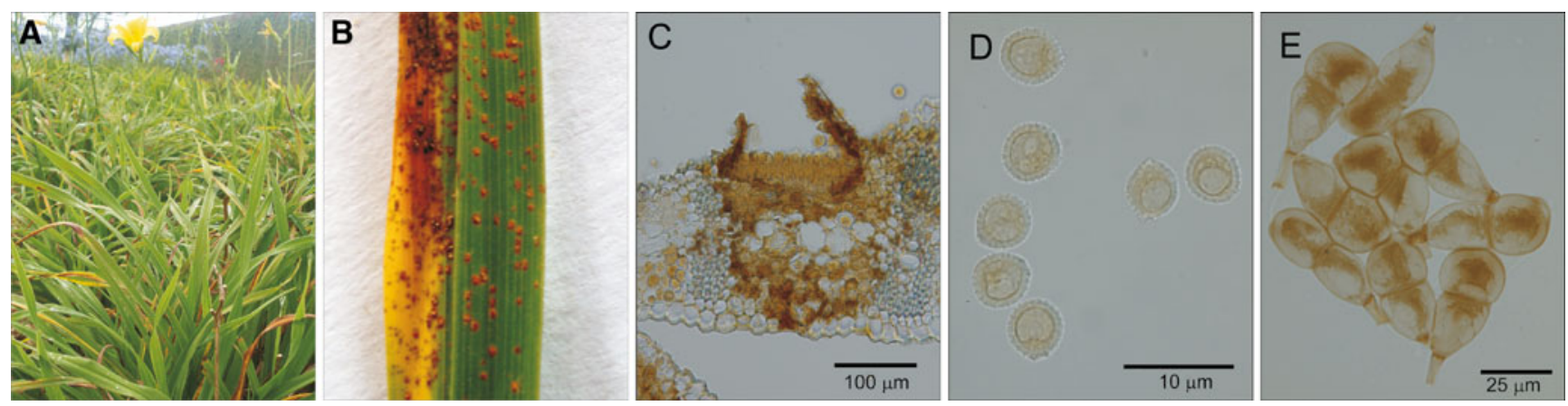

Fig. 1 a Rust symptoms on plants. b Close up of rust lesions on leaf. c Uredinia of Puccinia hemerocallidis. d Urediniospores of Puccinia hemerocallidis. e Teliospores of Puccinia hemerocallidis

South. It is now regarded as the major disease problem for daylily in Brazil.

\section{References}

Carvalho AA Jr, Coutinho LN, Figueiredo MB (2001) A primeira constatação da ferrugem do lírio-de-São-José nas Américas. Arq Inst Biol 68:55
Menezes SP, Pereira TS, Santos A, Novaes QS, Tavares GM, Junghans DT, Oliveira AC (2008) Ocorrência de Puccinia hemerocallidis em Hemerocallis no Estado da Bahia, Brasil. Magistra 20:403-405

Smith IM (2009) Puccinia hemerocallidis. Bull OEPP/EPPO 39:4850

Wise KA, Mueller DS, Buck JW (2004) Quarantines and ornamental rusts. APSnet. Retrieved September19, 2007 from http://www. apsnet.org/online/feature/quarantine/ 